\title{
ON THE ABILITY OF CALVES TO DIGEST HAY
}

\author{
AARNE MÄKELÄ \\ Department of Animal Husbandry, University of Helsinki \\ Received May 12, 1960
}

Microorganisms characteristic of adult cattle start to occur in the rumen of calves as early as at the age of two months, depending on the food (5). The best growth of protozoa and microflora is reached when the fodder ration consists of hay and moderate quantities of grain (11). According to ConRAD and HibBS (3) the digestibility of cellulose is less when a $2: 3$ ratio of hay to grain is given than when either $4: 1$ or $3: 2$ ratios are used.

The calf is able to digest grass at a very early age. According to Mc MEekAN (6) calves of 8 to 10 weeks and to PrEston et al. (12) calves of 3 weeks can digest the dry matter of fresh grass as efficiently as a mature cow. In the experiments of ConRaD et al. (2) with four calves aged 5-7 weeks the mean digestibility of pasture grass dry matter was 72 per cent and that of cellulose 82 per cent.

CONRAD et al. (2) have determined the digestibility of alfalfa hay in six calves less than two months old fed on hay ad lib. The mean digestibility of hay dry matter was 64 per cent and that of cellulose 63 per cent. The mean digestibility of crude fibre was in the experiment of BARTLEy et al. (1) with two calves 41.6 per cent at the age of 9 weeks and 44.3 per cent at the age of 13 weeks. The corresponding values from the experiments of PRITCHARD et al. (13) with 8 weeks old calves varied from 34 to 51 per cent. In these two experiments the hay was practically the only crude fibre containing ingredient of the ration. According to the digestibility trials of DAmmers et al. (4) with calves aged 60 days and fed on grain and hay, the calves digested 13 per cent less crude fibre, 10 per cent less crude protein and 4 per cent less $\mathrm{N}$-free extracts than grown sheep.

Rumen inoculations may increase the digestibility of roughage. ConRAD et al. (2) found that rumen-inoculated calves digested at the age of 5-7 weeks a statistically significant higher percentage of the dry matter and cellulose ingested than the uninoculated calves, but the difference in digestibility was temporary. According to the experiments of BARTLEY et al. (1) and PRITCHARD et al. in calves aged from 8 to 13 weeks (13) the administering of aureomycin had no marked or consistent effect on the digestibility of nutrients, except a reduction in the digestibility of crude fibre in some cases. 
Already at birth or at least two weeks after birth the calf has 8 incisor teeth and $4 \times 3$ premolar teeth. The eruption of the fourth cheek tooth occurs at the age of 5 to 6 months (15, p. 453 ).

According to the observations in this Institute six heifer calves consumed hay at the age of 2 months on an average $0.57 \mathrm{~kg}, 3$ months $1.22 \mathrm{~kg}, 4$ months 2.65 $\mathrm{kg}, 5$ months $3.16 \mathrm{~kg}$, and 6 months $3.82 \mathrm{~kg}$ daily, when hay and water were given ad lib. and milk and grain in moderate quantities (8).

\section{Experimental}

On the University Farm Viik three experiments with calves have been carried out in order to determine the digestibility of timothy hay with some red clover and cured at an early flowering stage. 16 Ayrshire calves, the ages of which varied from $2 \frac{1}{2}$ to 9 months and with a normal weight development, were used. They were given hay either entirely or almost ad lib. Also water was given ad lib. The experimental period lasted a minimum of 10 days. Samples of hay were taken either each day (Experiment 1), the last four days only (Experiment 2) or once from the hay reserved for the trial (Experiment 3). The quality of the hay was roughly the same in different experiments. The samples from faeces were taken on the last two days in Experiments 1 and 2 and in Experiment 3 only on the last day:

Before the digestibility trials the calves had been fed on a moderate milk and scanty concentrate diet while hay and water had been given ad lib.

Lignin was used as tracer. According to the investigation of SALO (14) the mean digestibility in sheep of lignin from mature hay or from hay cured after blooming was $1.8 \pm 0.6 \%$.

Experiment 1 was carried out in the spring 1954 with five heifer calves and one bull calf, the ages of which varied from 3 to 9 months. Hay was the only food and it was given in such large quantities that the refusals made up about one fourth of the amount given. A new ration of hay was given twice daily. Analyses were made separately from the hay given and from the refusals. In the dry matter of the hay eaten by the different calves the ash percentage varied $5.9-6.2$, the crude fibre $38.0-39.0$, the crude protein $8.4-9.0$, the lignin $9.4-9.5$, the percentage of $\mathrm{N}$-free extracts being about 44 . The digestibility of dry matter, organic matter, crude fibre, crude protein and $\mathrm{N}$-free extracts was determined.

Experiment 2 was carried out in autumn 1957 with six heifer calves and two cows for the sake of comparison. The experiment was divided into two phases each with three calves and two cows. The ages of the calves varied from 10 to 22 weeks. The calves received in addition to hay skimmilk and the two youngest calves also whole milk. Hay was the only food of the cows. The refusals came to $1 / 10-1 / 3$ of the amount given. A new ration of hay was given twice daily. Because the crude protein and crude fibre contents in the refusals were of the same magnitude as the contents in the hay that was offered, the composition is considered to be the same 
in the eaten hay as in the hay offered. The composition of hay in both phases was about the same. The dry matter of hay consisted of $7 \%$ ash, $9 \%$ crude protein, $8 \%$ lignin and $56 \%$ membrane substances $\left.{ }^{1}\right)$. The digestibility of organic matter, $\mathrm{N}$-free organic matter and membrane substances was determined.

Experiment 3 was carried out in the spring 1954 with three bull calves and one heifer aged about seven months, the weights varying between 160 to $180 \mathrm{~kg}$. After the experiment the calves were slaughtered and the contents of the reticulorumen, omasum, abomasum, small intestine and large intestine were weighed and sampled. From these samples as well as from the hay and the faeces the percentages of dry matter, ash, crude protein, and lignin were determined. The percentage of membrane substances was determined from the hay, the contents of the reticulorumen, and the faeces. On the ground of the analyses from the hay, the contents of the abomasum and faeces, the digestibility of $\mathrm{N}$-free organic matter and $\mathrm{N}$-free non-lignin organic matter was estimated in both the proventriculi and in the whole digestive tract. In the whole digestive tract the digestibility of organic matter and membrane substances was also estimated. Hay was the only food and it was given almost ad lib. New hay was offered three times daily at eight hour intervals. In the hay dry matter the percentage of ash was 7.2 , that of crude protein 10.0 , of lignin 8.8 , and of the membrane substances 56.6 .

\section{Results and discussion}

The digestibility of the hay constituents in Experiment 1 can be seen from Table 1 . The calves aged 5-9 months digested hay about equally when compared with each other. The youngest calf, aged 3 months, however, digested hay less efficiently than the older ones. The table shows that in several calves the digestibility of crude fibre is higher than that of $\mathrm{N}$-free extracts. This is so also in adult cattle, especially when the hay is coarse. It is apparently due to the fact that in food analysis the main part of lignin belongs to $\mathrm{N}$-free extracts.

$\left.{ }^{1}\right)$ Dedermined according to the method of PALOHErmo (10).

Table 1. The digestibility of hay in Experiment 1.

\begin{tabular}{|c|c|c|c|c|c|c|c|}
\hline \multirow{2}{*}{ Calf } & \multirow{2}{*}{\multicolumn{2}{|c|}{$\begin{array}{l}\text { Age, } \\
\text { months }\end{array}$}} & \multicolumn{5}{|c|}{ Digestibility percentages } \\
\hline & & & $\begin{array}{c}\text { Dry } \\
\text { matter }\end{array}$ & $\begin{array}{l}\text { Organic } \\
\text { matter }\end{array}$ & $\begin{array}{l}\text { Crude } \\
\text { fibre }\end{array}$ & $\begin{array}{c}\text { Crude } \\
\text { protein }\end{array}$ & $\begin{array}{c}\mathrm{N} \text {-free } \\
\text { extracts }\end{array}$ \\
\hline Mari & 우 & 3 & 45.3 & 47.5 & 47.3 & 24.0 & 52.1 \\
\hline Harri & $\hat{\sigma}$ & 5 & 52.5 & 54.1 & 57.4 & 42.3 & 53.6 \\
\hline Misa & 우 & 6 & 50.7 & 52.4 & 53.1 & 44.0 & 53.6 \\
\hline Misti & 우 & 6 & 51.2 & 52.5 & 54.9 & 48.2 & 51.4 \\
\hline Marina & 우 & $61 / 2$ & 55.0 & 56.8 & 60.0 & 49.1 & 55.5 \\
\hline Maissi & 우 & 9 & 53.6 & 55.2 & 56.8 & 49.2 & 55.4 \\
\hline
\end{tabular}


Table 2. Feeding of experimental animals and the digestibility of hay in Experiment 2.

\begin{tabular}{|c|c|c|c|c|c|c|}
\hline \multirow[b]{2}{*}{$\begin{array}{l}\text { Experimental } \\
\text { animal }\end{array}$} & \multirow[b]{2}{*}{ Age } & \multicolumn{3}{|c|}{ Feeding } & \multicolumn{2}{|c|}{ Digestiblity percentages } \\
\hline & & 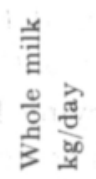 & 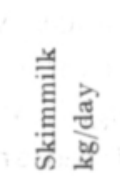 & 苛 & $\begin{array}{l}\text { 总点 } \\
\text { 焉 }\end{array}$ & 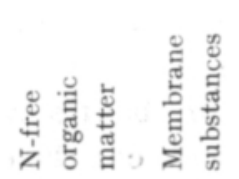 \\
\hline
\end{tabular}

The first phase of the experiment

$\begin{array}{clllllll}\text { Calves: } & & & & & & \\ \text { Aini } & 10 \text { weeks } & 1 & 8 & 1.5 & 52.9 & 57.9 & 53.0 \\ \text { Alli } & 17, & & 9 & 3.0 & 54.8 & 59.1 & 56.1 \\ \text { Ano } & 22, & & 6 & 5.1 & 54.5 & 57.6 & 54.1 \\ \text { Cows: } & & & & & & \\ \text { Lola } & 5 \text { years } & & & 10.7 & 61.2 & 62.3 & 58.2 \\ \text { Lallu } & 5 \text {. } & & & 13.0 & 61.2 & 61.2 & 58.3\end{array}$

Calves:

$\begin{array}{clllllll}\text { Alma } & 10 \text { weeks } & 1 & 8 & 1.0 & 44.9 & 50.5 & 47.8 \\ \text { Alla } & 12 & & 9 & 1.8 & 54.7 & 58.6 & 53.0 \\ \text { Aasa } & 17 & & 9 & 2.6 & 62.3 & 65.2 & 60.1 \\ \text { Cows: } & & & & & & & \\ \text { Nata } & 3 \text { years } & & & 12.2 & 61.3 & 62.3 & 61.9 \\ \text { Lallu } & 5 \text {, } & & & 13.0 & 61.8 & 63.2 & 59.9\end{array}$

The feeding of calves and control cows and the digestibility of hay in Experiment 2 is shown in Table 2 . In estimating the digestibility of the hay it has been assumed that milk is digested completely except for protein. Because the apparent digestibility of milk protein is not complete and because hay increases the secretion of endogenic nitrogen in the gut, the digestibility of protein has not been estimated. Owing to these facts the digestibility of organic matter in calves was $3-6$ per cent lower than that of $\mathrm{N}$-free organic matter. The digestibility of $\mathrm{N}$-free organic matter in the ration must equal that of the corresponding ingredient in hay, because milk fat and sugar are almost completely digested in calves (1). The digestibility of membrane substances in hay has been estimated because the said substances are characteristic of hay.

Compared with each other the control cows digested hay equally well. The calves, even when of the same age digested hay with varying efficiency. For instance the calf Aasa digested hay as efficiently as the cows, while with the calf Alli who was of the same age the digestibility was considerably less. The calf Aini again digested hay more efficiently than the calf Alma of the same age. The live weight of Aini was $81 \mathrm{~kg}$ and that of Alma only $67 \mathrm{~kg}$ at the age of 10 weeks. The ability of calves to consume hay also varies considerably. In the investigation carried out at this Institute (8) the amounts of hay eaten until 6 months of age varied from $270 \mathrm{~kg}$ to $370 \mathrm{~kg}$ in 17 calves when hay had been given ad lib. from birth. 
The calves aged 4-5 months seemed to digest hay almost as efficiently as adult cattle. The calves aged $10-12$ weeks, on the other hand, digested hay less efficiently.

The feeding of the calves and the digestibility of the hay as well as the fresh contents in the reticulo-rumen in Experiment 3 are shown in Table 3. In estimating the digestibility in the proventriculi a principle earlier used, in this Institute was applied (9): the contents of the abomasum were considered as an excrement of the proventriculi and the lignin ratio method was used. The share of the proventriculi in the digestibility of the $\mathrm{N}$-free organic matter and the $\mathrm{N}$-free non-lignin organic

Table 3. Feeding of the calves, digestibility of hay, and the contents in the reticulo-rumen in Experiment 3.

\begin{tabular}{|c|c|c|c|c|c|c|c|c|c|c|c|c|c|}
\hline \multirow[t]{2}{*}{ Calf } & \multirow{2}{*}{ 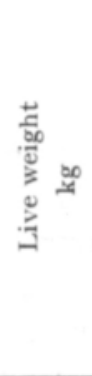 } & \multirow[b]{2}{*}{ 焉 } & \multicolumn{3}{|c|}{$\begin{array}{l}\text { Digestibility } \\
\text { in the } \\
\text { proventriculi } \\
\%\end{array}$} & \multicolumn{4}{|c|}{$\begin{array}{c}\text { Digestibility in the whole } \\
\text { digestive tract } \\
\%\end{array}$} & \multicolumn{2}{|c|}{$\begin{array}{c}\text { The share of } \\
\text { the proventriculi } \\
\text { in the digestibility } \\
\%\end{array}$} & \multicolumn{2}{|c|}{$\begin{array}{l}\text { Contents in the } \\
\text { reticulo-rumen }\end{array}$} \\
\hline & & & 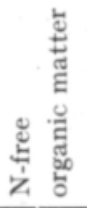 & 乙 & 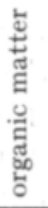 & 兽 & 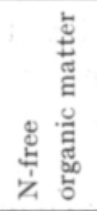 & 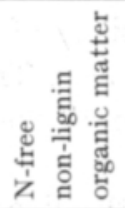 & 导 & 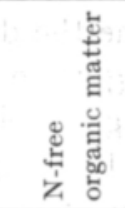 & 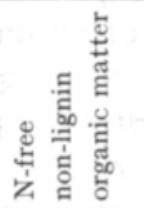 & 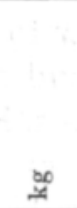 & 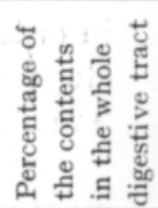 \\
\hline Puhto II ô & 170 & 4.41 & 45.5 & 50.8 & & 53.4 & 53.0 & 59.2 & 46.7 & 85.8 & 85.8 & 25.1 & 65.9 \\
\hline Ilta II $\widehat{\sigma}$ & 182 & 4.44 & 50.4 & 56.4 & & 57.5 & 57.4 & 64.2 & 53.1 & 87.8 & 87.9 & 38.1 & 75.6 \\
\hline Kaipu II $\widehat{\sigma}$ & 184 & 4.13 & 46.8 & 52.4 & & 57.3 & 57.1 & 63.8 & 52.3 & 82.0 & 82.1 & 39.3 & 73.5 \\
\hline Sapea 11 우 & 158 & 4.07 & 48.8 & 54.6 & & 56.6 & 56.7 & 63.4 & 50.3 & 86.1 & 86.1 & 34.4 & 77.5 \\
\hline
\end{tabular}

matter varied from 82 to 88 per cent of the corresponding digestibilities in the whole digestive tract. This share is of the same magnitude as in adult cows and in 7 months old bulls in earlier investigations carried out by this Institute (9). The digestibility of organic matter in the whole digestive tract was about the same as in the calves aged $4-9$ months in Experiments 1 and 2 .

The contents in the reticulo-rumen of 7 months old calves amounted to 30 $40 \mathrm{~kg}$. Because the calves consumed hay almost ad lib. and because eating continued nearly until the moment of slaughter, these figures possibly represent the class of magnitude of the physiological capacity of the reticulo-rumen, which is understood to mean the highest degree of fullness that can occur in the proventriculi as long as the vital functions are still taking place quite normally $(7, \mathrm{p} .17)$. The share of the proventriculi in the contents of the whole digestive tract amounted to $2 / 3-3 / 4$ or to the same amount as in cows $(7$, p. 69$)$. The contents of the reticulo-rumen amounted to $15-22 \%$ of the live weight. These precentages are higher than those found in cows $(7$, p. 69$)$.

The contents of the different parts of the digestive tract were weighed after the slaughtering of the four calves aged $3 \frac{1}{2}-4$ months and weighing about $100 \mathrm{~kg}$ 
each. During a minimum of 10 days before slaughtering the calves received $9 \mathrm{~kg}$ skimmilk daily and hay almost ad lib. The food was administered three times daily at even intervals. The amounts of the contents of the reticulo-rumen varied in different calves from 12 to $15 \mathrm{~kg}$. The share of the reticulo-rumen in the contents of the whole digestive tract varied from 70 to 75 per cent the percentages being of the same magnitude as in older calves and cows. The weights of the contents in the reticulo-rumen amounted to $12-16$ per cent of the live weights the percentages being about the same as those in cows but lower than those found in older calves. These observations agree with the results reported by Mc Meekan (6) according to which the calf at the age of 3 months has a rumen which in relation to its body weight is as large as that of an adult cow, and which becomes relatively larger at 5 months.

\section{$S u m m$ ar $y$}

Three experiments have been carried out with altogether 16 Ayrshire calves in order to determine the digestibility of timothy hay cured at the early flowering stage and containing some red clover. The ages of the calves varied from $2 \frac{1}{2}$ to 9 months. Hay was given either totally or almost ad lib. Lignin was used as tracer.

In experiment 1 the ages of the six experimental calves varied from 3 to 9 months. The calves aged 5-9 months digested hay equally efficiently when com-pared with each other. The youngest calf aged 3 months digested hay less efficiently (Table 1).

In Experiment 2 the ages of the six experimental calves varied from 10 to 22 weeks. In the trial two control cows were also included. The calves aged 10-12 weeks digested hay less efficiently and the calves aged $4-5$ months almost as efficiently as the control cows (Table 2). The ability of calves of the same age to digest hay was quite variable.

Experiment 3 was carried out with four 7 months old calves. At the end of the trial the calves were slaughtered and the contents of the different parts of the digestive tract were weighed and sampled. On the ground of the analyses of the hay, the contents of the abomasum and the faeces, the digestibilities of $\mathrm{N}$-free organic matter and $\mathrm{N}$-free non-lignin organic matter in the proventriculi and in the whole digestive tract were esimated. The share of the proventriculi in the total digestibility of the said substances was $82-88$ per cent (Table 3).

The contents of the reticulo-rumen of the calves in Experiment 3 as well as those of younger calves aged $31 / 2-4$ months were weighed in connection with the slaughtering. The quantity of the contents in calves of 7 months was $30-40 \mathrm{~kg}$ and that in calves aged $3 \frac{1}{2}-4$ months $12-15 \mathrm{~kg}$. 


\section{REFERENCES}

(1) Bartley, E. E. \& Parrish, D. B. \& Wheatcroft, K. L. 1956. Antibiotics in dairy cattle nutrition. 6. The effects of aureomycin feeding on the apparent digestibility of certain calf rations. J. Dairy Sci. 39: 319-325.

(2) Conrad, H. R. \& Hibbs, J. W. \& Pounden, W. D. \& Sutton, T. S. 1950. The effect of rumen inoculations on the digestibility of roughages in young dairy calves. Ibid. $33: 585-592$.

(3) Conrad, H. R. \& HibBs, J. W. 1953. The effect of rumen inoculations and the ratio of hay to grain eaten on the digestion and nitrogen retention in high roughage fed calves. Ibid. $36: 600-601$.

(4) Dammers, J., Dijkstra, N. D. \& Frens, A. M. 1951. Proeven omtrent de voedering van kalveren gedurende de eerste levensmaanden. Versl. Landsbouwk. Onderzoek. s'Gravenhage. No. 57. 9. Ref. Nutrition Abstr. \& Rev. 1952, 22: 253.

(5) Huhtanen, C. N., Saunders, R. K. \& Gall, L. S. 1951. Some differences in adult and infant rumen flora of caftle on pràctical rations. J. Animal Sci. 10: 1049-1050.

(6) Mc Meekan, C. P. 1954. Good rearing of dairy stock. Reprinted from the April, May and June 1954 issues of "The New Zealand Journal of Agriculturen, p. 1-31.

(7) MäKELÄ, A. 1956. Studies on the question of bulk in the nutrition of farm animals with special reference to cattle. Acta agr. fenn. 85,130 p.

(8) - - 1958. Viikin opetus- ja koetilalla noudatettu lehmävasikoitten ruokintajärjestelmä. J. Sci. Agric. Soc. Finland 30: 276-292.

(9) Palohetmo, L. \& MÄkelä, A. \& Salo, M.-L. 1955. Some quantitative data on the role of the ruminant proventriculi in the digestion and absorption of nitrogen-free organic matter. Ibid. 27: 70-76.

(10) Paloheimo, L. \& Paloheimo, IrJa 1949. On the estimation of the total of vegetable membrane substances. Ibid. $21: 1-16$.

(11) Pounden, W. D. \& HibBs, J. W. 1948. The influence of the ratio of grain to hay in the ration of dairy calves on certain rumen microorganisms. J. Dairy Sci. 31: 1051-1054.

(12) Preston, T. R. 1956. Studies on the rearing of calves weaned from milk between two and four weeks of age. Proc. Brit. Soc. of Animal Production, p. 67-77.

(13) Pritchard, G. I., Newlander, J. A. \& Riddel, W. H. 1955. Aureomycin effects-growth and digestibility studies with identical twin calves. J. Animal Sci. 14: 336-339.

(14) Salo, Marja-Lirsa 1958. Lignin studies. III. Lignin as tracer in digestibility investigations. J. Sci. Agric. Soc. Finland 30: 97-104.

(15) Sisson, S. \& Grossman, J. D. 1938. The anatomy of the domestic animals. 972 p. Philadelphia and London.

\section{S E L OS T U S :}

\section{VASIKOITTEN KYVYSTÄ SULATTAA HEINIÄ}

\section{AARNE MĀKELÄ}

\section{Kotieläintieteen laitos, Helsingin yliopisto}

Viikin koetilalla on suoritettu kolme koetta aikaisessa kukintavaiheessa korjatun ja hieman apilaa sisältävän timoteiheinän sulavuuden selvittämiseksi vasikoilla. Kokeissa oli kaiken kaikkiaan 16 Ayrshire-vasikkaa, joiden ikä vaihteli 2 1/2-9 kuukauteen. Heiniä annettiin joko täysin tai melkein vapaasti. Ligniiniä on pidetty johtoaineena.

1. Kokeessa 1 oli kuusi $3-9$ kuukauden ikäistä vasikkaa. Näistä 5-9 kuukauden ikäiset sulattivat heiniä keskenäăn verrattuina suunnilleen yhtä hyvin. Orgaanisen aineen sulavuus vaihteli $52-$ $57 \%$. Nuorin, 3 kuukauden ikäinen vasikka, sulatti heiniä heikommin. 
2. Kokeessa 2 oli kuusi $10-22$ viikon ikäistä vasikkả ja kaksi vertailulehmää. Nuorimmat vasikat, joitten ikä oli $10-12$ viikkoa, sulattivat heiniä heikommin kuin vertailulehmät. Typettömän orgaanisen aineen sulavuus oli edellisillä $51-59 \%$ ja jälkimmäisillä $62-63 \%$. Sensijaan $4-5$ kutukauden ikäiset vasikat sulattivat heiniä lähes yhtä hyvin kuin lehmät. Samanikäistenkin vasikoitten kyky sulattaa heiniä vaihteli huomattavasti.

3. Kokeessa 3 oli neljä n. 7 kuukauden ikäistä vasikkaa, jotka kokeen päättyessä teurastettiìh. Rehusta,-juoksutusmahan sisällöstä ja sonnasta suoritettujen analyysien perusteella arvioitiin typettömän orgaanisen aineen sekä typettömän ligniinivapaan orgaanisen aineen sulavuudet sekä esimahoissa että koko ruoansulatuskanavassa. Esimahojen osuus näitten aineitten sulavuudessa oli $82-$ $88 \%$. Typettömän orgaanisen aineen sulavuus koko ruoansulatuskanavassa oli $53-57 \%$.

4. Kokeessa 3 olleitten vasikoitten samoinkuin neljän $3 \frac{1}{2}-4$ kuukauden ikäisen vasikan pötsiverkkomahan sisăllöt punnittiin teurastuksen yhteydessã. Edellisillä sisällön määrä oli $30-40 \mathrm{~kg}$ ja jälkimmäisillä $12-15 \mathrm{~kg}$. 